\title{
Physical Activity Improves Muscle Strength and Reduces Inflammatory Markers in Diabetic Elderly Patients
}

\section{Aktifitas Fisik Meningkatkan Kekuatan Otot dan Mengurangi Tanda-tanda Inflamasi pada Pasien Lansia dengan Diabetes}

\author{
Lailatul Fitriyah, Sri Sunarti
}

Laboratorium IImu Penyakit Dalam Rumah Sakit Umum Daerah Dr. Saiful Anwar Malang

\begin{abstract}
Regular exercise has an effect on muscle strength and inflammatory markers. The aim of this study is to determine the relation of regular exercise with muscle strength and inflammatory markers (IL-6, CRP) in diabetic elderly compared to non-diabetic ones. A case control study was conducted to 30 elderly by giving them regular exercise. Fifteen subjects were diabetic and the other fifteen were non-diabetic. The data were analyzed using Chi-Square, independent $t$-Test and Mann Whitney. The result shows handgrip $24,9(14,8-34,6) \mathrm{kg}$ in diabetic vs. $25(6,8-42,1) \mathrm{kg}$ in non-diabetic $(p=0,673) ; 4$ meters walk was $3,38(2,34-8,18)$ s in diabetic vs $3,26(2,06-4,36)$ s in non-diabetic $(p=0,263) ; \quad l L-6$ level was $1,61(0,37-14,02) \mathrm{pg} / \mathrm{mL}$ in diabetic vs $1,47(0,52-10,17) \mathrm{pg} / \mathrm{mL}$ in non-diabetic $(p=0,983)$; CRP level was $0,23(0,18-0,33) \mathrm{mg} / \mathrm{dL}$ in diabetic vs $0,22(0,11-1,01) \mathrm{mg} / \mathrm{dL}$ in non-diabetic $(p=0,622)$. HbA1C was $7,35(5,9-13) \%$. There is no significant difference in muscle strength and inflammatory markers on the diabetic and non-diabetic groups who exercise regularly. This study shows that regular exercise and well-controlled HbA1C give a good impact on muscle strength and inflammatory markers of the diabetic elderly patients.
\end{abstract}

Keywords: CRP, diabetes, IL-6, elderly, exercise

\section{ABSTRAK}

Olahraga teratur memiliki efek pada kekuatan otot dan marker inflamasi. Tujuan dari penelitian ini adalah untuk mengetahui hubungan olah raga teratur dengan kekuatan otot dan marker inflamasi (IL-6, CRP) pada lansia diabetes dibandingkan dengan lansia non-diabetes. Penelitian case control dilakukan pada 30 lansia dengan olah raga teratur. 15 subjek diabetes dan 15 subjek non-diabetes. Analisa data menggunakan Chi-Square, independent t-Test dan MannWhitney. Hasil penelitian menunjukkan handgrip $24,9(14,8-34,6) \mathrm{kg}$ pada diabetes vs $25(6,8-42,1) \mathrm{kg}$ pada non-diabetes $(p=0,673)$; jalan 4 meter $3,38(2,34-8,18)$ detik pada diabetes vs $3,26(2,06-4,36)$ detik pada non-diabetes ( $p=0,263)$; IL-6 $1,61(0,37-14,02) \mathrm{pg} / \mathrm{mL}$ pada diabetes vs $1,47(0,52-10,17) \mathrm{pg} / \mathrm{mL}$ pada non-diabetes $(p=0,983) ; C R P$ 0,23(0,18$0,33) \mathrm{mg} / \mathrm{dL}$ pada diabetes vs $0,22(0,11-1,01) \mathrm{mg} / \mathrm{dL}$ pada non-diabetic $(p=0,622)$. HbA1C 7,35 (5,9-13)\%. Tidak didapatkan perbedaan bermakna pada kekuatan otot dan marker inflamasi pada pasien lansia diabetes dan non-diabetes yang melakukan olahraga teratur. Penelitian ini menunjukkan olahraga teratur dan HbA1C yang terkontrol memiliki efek yang baik pada kekuatan otot dan marker inflamasi pada lansia dengan diabetes.

Kata Kunci: CRP, diabetes, IL-6, lansia, olahraga

Jurnal Kedokteran Brawijaya, Vol. 28, No. 2, Agustus 2014; Korespondensi: Lailatul Fitriyah. Laboratorium Ilmu Penyakit Dalam Rumah Sakit Umum Daerah Dr. Saiful Anwar Malang, Jl. Jaksa Agung No. 2 Malang Tel. (0341)366242 Email: ella_x_yz@yahoo.com 


\section{INTRODUCTION}

The proportion of population aged 60 years in Indonesia is projected to exceed $12 \%$ by 2020 . This condition is associated with the major increase in the number of people with diabetes $(1,2)$. Health $A B C$ study showed that in community-dwelling, elderly with type 2 diabetes is associated with accelerated loss of leg muscle strength and quality. These characteristics may contribute to the development of physical disability in elderly with diabetes. A few studies also showed that diabetes has been associated with a two to threefold increased risk of developing physical disability (3-6).

Growing evidence links type 2 diabetes to a state of lowgrade chronic inflammation and it has been suggested that Interleukin (IL)- 6 promotes insulin resistance and has detrimental effects on muscle mass, strength, and physical performance in elderly $(7,8)$. Cesari et al reported that there was an inverse relation between C-Reactive Protein (CRP) and IL- 6 with appendicular muscle mass. That study was similar to Taaffe et al which showed that high level of IL-6 and CRP was associated with lower handgrip. The increase of IL- $6>5 \mathrm{pg} / \mathrm{ml}$ and CRP $>6,1 \mu \mathrm{g} / \mathrm{ml}$ were associated with two until threefold risk of muscle mass loss by $40 \%$ in 3 years (9). This data showed that inflammation has been association with the loss of muscle mass and muscle strength.

Aerobic and resistance exercise effectively improve insulin sensitivity and lead to better glycemic control in patients with diabetes (11). Regular exercise also has a good impact on decreasing IL- 6 and CRP which means decreasing the inflammation process. However, the effects of diabetes on muscle strength and inflammatory markers have never been investigated in Indonesia which has different culture and life style. We hypothesized that regular exercise will improve muscles strength and decrease the inflammatory markers in elderly diabetic patients.

\section{METHODS}

\section{Subjects}

Subjects were collected using consecutive sampling, from May-July 2013 in Geriatric-Diabetes Outpatient Clinic of RSSA Malang and 5 districts in Malang. Three hundred and thirty five subjects who community-dwelling, aged above 60 years were recruited and consisted of 35 diabetic and 300 non-diabetic. All subjects then were interviewed about their regular exercise which is defined as walking more than 150minutes/week. They were given detailed interview on their past medical history and comorbidities. From 35 diabetic subjects, 15 subjects who fulfill the inclusion criteria and 15 non-diabetic subjects as control were taken. The inclusion criteria were community-dwelling aged above 60 years and exercise regularly. Regular exercise was defined as walking 150 minutes/week for at least 6 months.

The exclusion criteria were disabled or used supportive device for walking which could interfere the walking speed and any severe concurrent illness. All diabetics were well controlled with insulin injections or oral antidiabetes agents such as sulfonylurea alone or combined with metformin or acarbose. All patients monitored their blood glucose and HbA1c. Non-diabetic is defined as community-dwelling, aged above 60 years with no comorbidities and exercise regularly. All subjects were fully informed on the purpose of the study and gave their informed consent to take part in the study. The university ethics committee accepted the protocol.

\section{STUDY DESIGN}

\section{Bodycomposition}

Body weight was measured on an electronic scale to the nearest $0,1 \mathrm{~kg}$. Body height was measured by knee height with formulation $59,01+(2,08 \times k$ nee height $)$ for men and $75+(1,91 \times$ knee height $)-(0,71$ xage(year) $)$ for women. Waist circumference at the umbilical midline was measured to the nearest $\mathrm{cm}$ with flexible tape. Arm circumference at the half of scapula-elbow was measured to the nearest $\mathrm{cm}$ with flexible tape. Sarcopenia was measured by formulation of MMAC and MMLee.

\section{Muscle Strength}

Three consecutive measurements of handgrip strength of the dominant hand were performed with a calibrated dynamometer (Takei Scientific Instruments, Tokyo, Japan), which was reset to zero before each measurement. The measurements were conducted under standardized conditions: subject stand-up, left leg one step ahead and right hand across the abdomen, the shoulder adducted and neutrally rotated, with the elbow at 90 ० flexion and the fore arm and wrist in a neutral position. Patients were encouraged to use a standard phraseology (squeeze the handle as hard as possible). Mean values were recorded.

\section{Inflammatory Markers}

Interleukin-6 (IL-6) level were measured in duplicate using an ultrasensitive enzyme-linked immunosorbent assay. Recombinant IL-6, purified CRP, and pooled human plasma were used as standards in the respective assays and results were expressed as picograms/milliliter. C Reactive Protein (CRP) level was measured using turbidimetry and results were expressed as milligram/deciliter.

\section{Other Covariates}

Other covariates measured are socio-demographic characteristics included age and sex. Combined chronic diseases such as coronary heart disease, congestive heart failure, stroke, peripheral artery disease, knee osteoarthritis, depression, and cancer were identified by self-report and was confirmed by treatment and medication use. Self-reported poor eyesight was considered as impaired vision. Renal insufficiency was defined by serum creatinine level $>1,5 \mathrm{mg} / \mathrm{dl}$ in men and $1,2 \mathrm{mg} / \mathrm{dl}$ in women (15).

\section{Statistical Analysis}

Data are shown as means with standard deviation if the data have normal distribution and median with range of minimum-maximum if the data have skewed distributions. Analyses were performed using SPSS 16. Characteristics of subjects with type 2 diabetes and non-diabetes as control were compared using Chi-Square tests, independent $t$ tests and Mann-Whitney tests, $\mathrm{p}<0,05$ was considered significant.

\section{RESULTS}

The baseline demographic and interview variables of the subjects in the two groups are summarized in Table 1. Thirty elderly subjects with complete assessment were included which consists of 15 diabetic and 15 non-diabetic. The age, gender, arm circumference and sarcopenia were similar in both groups. All non-diabetic subjects as control 
had no co-morbidities. Body mass index and abdomen circumference were significantly higher in diabetic subjects $(p=0,032$ and $p=0,001)$. HbA1c in diabetes was $7,35(5,9-13) \%$ with $15 \pm 4,93$ years of diabetes-duration, $3,57 \pm 2,64$ years of insulin-duration.

Table 1. Selected variable characteristics of participants at baseline according to study group

\begin{tabular}{|c|c|c|c|}
\hline & $\begin{array}{l}\text { Non-Diabetic } \\
\text { (n=15 subjects) }\end{array}$ & $\begin{array}{c}\text { Diabetic } \\
\text { ( } n=15 \text { subjects) }\end{array}$ & p value \\
\hline Age & $70(64-86)^{\dagger}$ & $72,33 \pm 6,10^{*}$ & $p=0,463$ \\
\hline \multicolumn{4}{|l|}{ Gender } \\
\hline Men & $7(47 \%)$ & $10(67 \%)$ & $p=0,461$ \\
\hline Women & $8(53 \%)$ & $5(33 \%)$ & \\
\hline \multicolumn{4}{|l|}{ Co-morbidities } \\
\hline Yes & - & $6(40 \%)$ & $\mathrm{p}=0,017^{* *}$ \\
\hline No & $100 \%$ & $9(60 \%)$ & \\
\hline Body Mass Index & $23,75 \pm 4,14^{*}$ & $26,63 \pm 2,67^{*}$ & $p=0,032 * *$ \\
\hline Arm circumference & $29,43 \pm 5,11^{*}$ & $30(27-38,5) \dagger$ & $p=0,618$ \\
\hline Abdomen circumference & $84,67 \pm 8,89 *$ & $97,90(83-116)^{\dagger}$ & $\mathrm{p}=0,001 * *$ \\
\hline \multicolumn{4}{|l|}{ Sarcopenia MMAC } \\
\hline Yes & & $3(20 \%)$ & $p=0,224$ \\
\hline No & $15(100 \%)$ & $12(80 \%)$ & \\
\hline \multicolumn{4}{|l|}{ Sarcopenia MMLee } \\
\hline Yes & & $3(20 \%)$ & $p=0,224$ \\
\hline No & $15(100 \%)$ & $12(80 \%)$ & \\
\hline HbA1c & & $7,35(5,9-13)+* * *$ & \\
\hline Diabetes duration & & $15 \pm 4,93^{*}$ & \\
\hline \multicolumn{4}{|l|}{ Diabetes treatment } \\
\hline OAD & & $11(73 \%)$ & \\
\hline Insulin & & $4(27 \%)$ & \\
\hline Insulin duration & & $3,57 \pm 2,64^{*}$ & \\
\hline
\end{tabular}

*mean \pm standard deviation; +median (minimum-maximum); $* * p<0,05$ statistically significant

$* * *$ there are 5 missing data

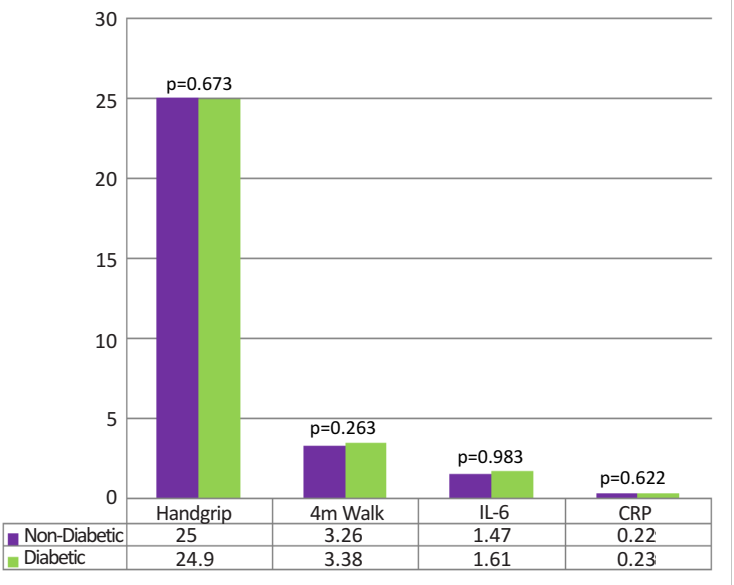

Figure 1. The Differences on muscle strength and inflammatory marker between diabetic and non diabetic

\section{DAFTAR PUSTAKA}

1. Wild S, Roglic G, Green A, Sicree R, and King H. Global Prevalence of Diabetes: Estimates for the Year 2000 and Projections for 2030. Diabetes Care. 2004; 27(5): 1047-1053.

2. Boyle JP, Honeycutt AA, Narayan KM, et al. Projection of Diabetes Burden through 2050: Impact of Changing Demography and Disease Prevalence in the U.S. Diabetes Care. 2001; 24(11): 1936-1940.
In Figure 1 data were shown using median. The statistic test used were Independent T test and Mann-Whitney test for categorical-numeric variables.

Figure 1 shows that there is no differences on muscle strength and inflammatory markers: handgrip $(p=0,673)$, $4 \mathrm{~m}$ walk $(p=0,263), \operatorname{IL}-6(0,983), \operatorname{CRP}(0,622)$ between elderly diabetic and non-diabetic patients who exercise regularly.

\section{DISCUSSION}

This study observes the differences of muscle strength and inflammatory markers in elderly diabetic and non-diabetic patients who exercise regularly. Wild et al showed that aerobic and resistance exercise effectively improve insulin sensitivity and lead to better glycemic control in patients with diabetes. Kim HK et al demonstrated that exercise and amino acid supplementation together have significant effects on enhancing not only muscle strength and walking speed in community-dwelling elderly Japanese sarcopenic women. The present study also shows that there is no differences on muscle strength and inflammatory markers between diabetic and non-diabetic elderly who exercise regularly. Hand is an important target for diabetic musculoskeletal complication. The pervious study showed that handgrip values were significantly lower in diabetic group compared to control non-diabetic (13). Distal symmetrical neuropathy which may present sub-clinically is responsible for muscle weakness and attributes to low grip strength. Another potential mechanism is increased levels of inflammatory cytokines in subjects with diabetes. It has been reported that high level of IL- 6 and CRP was associated with lower handgrip (10). In this study, muscle strength which is showed by hand grip, walking speed and inflammatory markers of CRP and IL- 6 of diabetic subjects were significantly similar to those of non-diabetic subjects.

In this study, diabetic subjects showed well controlled $\mathrm{HbA1C}$ (median 7,35\%) with the duration of diabetes of $15 \pm 4,93$ years. It has been known that insulin treatment influences lipid and protein metabolism with anabolic and anti-catabolic effects. There were 4 subjects who use insulin with the duration of insulin treatment of $3,57 \pm 2,64$ years. Although exercise already shows to have a good impact on muscle strength, well controlled $\mathrm{HbA1C}$ is also important to improve muscle strength in diabetic subjects, but further follow up studies on larger population are required to confirm the effect of insulin treatment on muscle strength and inflammatory markers.

This study demonstrates that regular exercise has a good impact on muscle strength and inflammatory markers in diabetic elderly. We strongly advise regular exercise for diabetic patient since it makes the muscle strength and inflammatory markers achieved the same level as those of non-diabetic and finally could improve physical activity in elderly diabetic patients.

3. Gregg EW, Beckles GL, Williamson DF, et al. Diabetes and Physical Dis-Ability Among U.S. Adults. Diabetes Care. 2000; 23(9): 1272-1277.

4. Gregg EW, Mangione CM, Cauley JA, et al. Diabetes and Incidence of Functional Disability on Older Women. Diabetes Care. 2002; 25(1): 61-67.

5. Ryerson B, Tierney EF, Thompson TJ, et al. Excess Physical Limitations among Adults with Diabetes in the U.S. Population, 1997-1999. Diabetes Care. 2003; 
26(1): 206-210.

6. De Rekeneire N, Resnick HE, Schwartz AV, et al. Diabetes is Associated with Subclinical Functional Limitation in Nondisabled Older Individuals: The Health, Aging, and Body Composition Study. Diabetes Care. 2003; 26(12): 3257-3263.

7. Cesari M, Penninx BW, Pahor $\mathrm{M}$, et al. Inflammatory Markers and Physical Performance in Older Persons: the in CHIANTI Study. The Journals of Gerontology Series A: Biological Sciences and Medical Sciences. 2004; 59(3): 242-248.

8. Visser M, Pahor M, Taaffe DR, et al. Relationship of Interleukin 6 and Tumor Necrosis Factor a with Muscle Mass and Muscle Strength in Elderly Men and Women: The Health $A B C$ Study. Journal of Gerontology Series A: Biological Sciences and Medical Sciences. 2002; 57(5): M326-M332.

9. Schaap LA, Pluijn SMF, Deeg DJ, and Visser M. Inflammatory Markers and Loss of Muscle Mass (Sarcopenia) and Strength. The American Journal of Medicine. 2006; 119(6): 526.e9-526.e17.

10. Taaffe DR, Harris TB, Ferrucci L, Rowe J, and Seeman
TE. Cross-Sectional and Prospective Relationships of Interleukin-6 and C-Reactive Protein with Physical Performance in Elderly Persons: MacArthur Studies of Successful Aging. Journal of Gerontology Series A: Biological Sciences and Medical Sciences 2000; 55(12): M709-M715.

11. Poehlman ET, Dvorak RV, de Nino WF, Brochu M, and Ades PA. Effects of Resistance Training and Endurance Training on Insulin Sensitivity in Non-Obese, Young Women: A Randomized Controlled Trial. Journal of Clinical Endocrinology and Metabolism. 2000; 85(7): 2463-2468.

12. Kim HK, Suzuki T, Saito K, et al. Effects of Exercise and Amino Acid Supplementation on Body Composition and Physical Function in Community-Dwelling Elderly Japanese Sarcopenic Women: A Randomized Controlled Trial. Journal of the American Geriatrics Society. 2012; 60(1): 16-23.

13. Sindhur JC and Sanjay P. Comparative Study to Determine the Hand Grip Strength in Type-II Diabetes versus Non-Diabetic Individuals-A Cross Sectional Study. Indian Journal of Physiotherapy \& Occupational Therapy. 2013; 7(1): 243-245. 